\title{
Perceptions of agro-pastoralists towards the change in temperature and precipitation in the trans-Himalayan regions of Nepal
}

\begin{abstract}
S. Aryal ${ }^{1 *, 2}$, S. K. Ghimire ${ }^{2}$, Y. R. Dhakal ${ }^{2,3}$, N. P. Gaire ${ }^{2,3,4}$ and S. Bhandari ${ }^{4}$
Climate change has emerged as a global concern despite its differential impacts across geographical, social and economic gradients. Understanding perceptions of local communities towards climate change is important as it advances the knowledge, and is the driver of autonomous adaptation and behavioral responses. The livelihood of the agro-pastoralists in the trans-Himalayan regions of Nepal depends on the natural resources, and is highly sensitive to the change in climatic variables. Although there are indications of pronounced climate change in terms of their important variables in the high-altitude compared to the lowland of Nepal, there is limited information on how communities living in those areas have perceived to the change. Realizing the significance of such information, perceptions of the agro-pastoralists towards the change in climatic variables were studied in the two important high-and trans-Himalayan districts- Dolpa and Mustang. The results of the study revealed that the perceptions of the agro-pastoralists correspond with the increasing trend of temperature and the changing (both increasing and decreasing) trends of precipitation. Moreover, the agropastoralists have perceived the decrease in snowfall and reported appearance of new forage and pasture species in rangelands. The findings will be useful to understand about the climate change in the high- and trans-Himalayan region, and to devise adaptation strategies in these areas.
\end{abstract}

Key words: Agro-pastoralists, climate change, impacts, Nepal, perceptions and trends

A 1though impacts of climate change differ across geographical, socio-political and economic gradients, climate change has emerged as a global concern (MEA, 2005). Small island, least- developed and mountainous countries are more vulnerable to climate change (Klein, 2009). Due to its geo-political conditions and its potential impact on the economy, ecology, and environment, climate change is a major concern in the Himalayas (Liu and Rasul, 2007). The rate of increase in temperature is higher than the global average in the region, and the form of precipitation will be changed in the higher Himalayas where more rainfall will be expected than the snowfall (IPCC, 2007).

Nepal is both the mountainous and the least developed country of the Himalayan region which is socio-politically, geographically and economically fragile. Climate change has emerged as a systematic threat compounding with other threats challenging the livelihood of people and sustainability of the traditional systems. The trends of temperature suggest that warming is more pronounced in the high-altitude areas than in the lower elevations of Nepal, and the nature of precipitation has also been changing (NAPA, 2010; Shrestha and Aryal, 2011). Previous studies (Gentle and Maraseni, 2012; Aryal et al., 2014a; Macchi et al., 2014) suggest that the climate change has affected the livelihood of the people in the mountainous areas of Himalayas. But, people living with high-poverty in the region have limited capacity to adapt with the climate change.

Over two million Nepalese depend upon climate sensitive sectors like agriculture and forestry for their livelihood (Garg et al., 2007). Even with a slight change on climatic variables, there would

${ }^{1}$ Institute for Agriculture and the Environment, University of Southern Queensland, QLD 4350, Australia;

*E-mail: aaryalsuman@gmail.com

2 Siddhartha Environmental Service, Kathmandu, Nepal

${ }^{3}$ Tree Ring Society of Nepal, Lalitpur, Nepal

${ }^{4}$ Nepal Academy of Science and Technology (NAST), Lalitpur, Nepal 
be a greater impact over the natural and human systems of Nepal. Agro-pastoralism is practiced in those areas which are most affected by global climate change (Kullman, 2004; Zomer et al. 2014) and are likely to be affected by the timing of rainfall, agricultural seasons, persistence and melting of snow in rangelands, availability of water near grazing spots and so on. The agropastoralists may be disproportionately more vulnerable due to climate change (Dong et al., 2011) and the situation could be even more severe when the flexibility is restricted (Tyler et al., 2007; Fu et al., 2012).

The observations of local people often relied on holistic ways of knowing their environment that integrate a number of variables and relationships between them (Pretty et al., 2009). Local people use physical environmental indicators such as rain, first snowfall, melting of snow and biological indicators such as spring budding, leafing, blooming flowers and fruiting (Turner and Clifton, 2009). Perceptions in some instances, however, can be affected by their belief on climate change (Howe et al., 2013; Niles and Mueller, 2016). The indigenous and marginalized communities whose subsistence livelihoods depend upon direct utilization of natural resources might have different experiences and knowledge than the people adopting a modern lifestyle and living in urban areas (Tucker 1986; Wolf and Moser 2011; Howe et al., 2014). Many scholars (Petheram et al., 2010; Alexander et al., 2011; SánchezCortés and Chavero, 2011) have noted that indigenous knowledge could be better applied to the assessments of climate change. It has also been acknowledged for its role in advancing the understanding of climate change (Nelson et al., 2006; Chaudhary and Bawa, 2011; Klein et al., 2014). In these contexts, agro-pastoralists of the high Himalayas have to respond to nature's rhythm for characteristic seasonal movement of livestock and crop plantation and harvesting. Their perceptions and meaningful observations could be interesting in climate change studies and to understand impacts of climate change to the climate sensitive agro-pastoral systems. Therefore, this study aims to explore the perceptions of the agro-pastoralists towards change in climatic variables, validate perceptions with the trends and impacts of climate change to the agro-pastoralism in the high-altitude and trans-Himalayan regions of Nepal.

\section{Materials and methods}

\section{Study area}

The study was conducted in the Dolpa district of the Mid-western Development Region and the Mustang district of the Western Development Region of Nepal. Both the Dolpa and Mustang districts are mountainous districts of Nepal, and represent the trans-Himalayas. The field visits at the study sites were conducted by a Team including one Expert in Climate Change and Agro-pastoralism, and three Research Assistants. The same Team conducted the study in both the sites. The field visit in the Mustang district was conducted during September October, 2015 whereas it was conducted in April in the Dolpa district. Preliminary consultation was done with the staff of the Annapurna Conservation Area Project (ACAP) Site Office and the members of the Conservation Area Management Committee in the case of Mustang district and the staff of the Shey Phoksundo National Park Office in the case of Dolpa district. As this paper is a part of a broader research project entitled "Treeline Shift in the Central Nepal Himalaya and the Climate Reconstruction of the Past Millennia", the local people who frequently visit the forest area especially for yak movement and sheep rearing were consulted to identify the study sites.

\section{Data collection}

After the selection of the study sites for dendrological and ecological study, the local people who were using the forests and rangelands near the dendrological study sites were selected for survey and focus group discussions (FGDs). Based on the criteria described above, three sites viz. Marpha Settlement of the Marpha VDC, Kodekhola Danda and Kosari Ban were selected in the case of Mustang district whereas Rigmu and Chhekpa of the Phoksundo VDC in the Dolpa district were selected for the survey and FGDs (Fig. 1). A total of 21 agro-pastoralists in the Dolpa district and 15 in the Mustang district were surveyed using semi-structured questionnaire. A purposive sampling method was applied for the selection of the respondents for the survey as no prior list of the agro-pastoralists was available. At first, the secretaries of the selected VDCs were approached to identify the initial contacts of some agro-pastoralists, and then the contacted agropastoralists were asked to identify the other agro- 
pastoralists.

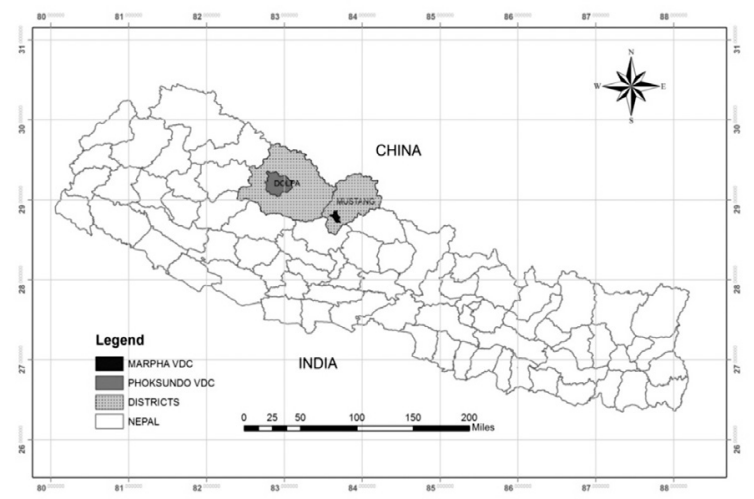

Fig. 1: District map of Nepal showing the study areas

A face-to-face and semi-structured interview was done with the selected respondents, and the perceptions of the herders about the two major climatic variables- temperature and precipitation were collected, asking whether the particular variable was changing or not. The responses were categorized in the 'yes', 'no' and 'don't know' columns. If the answer was 'yes', the trend of change (increasing or decreasing) was also noted.

Two focus groups discussions (FGDs) were also conducted in each site in a group of 6-8 agropastoralists per FGD. The likely impacts of climate change to the agro-pastoralism were also discussed during the FGDs.

The temperature and precipitation data for trend analysis were collected from the meteorological stations under the Department of Hydrology and Meteorology (DHM). The nearest meteorological stations from the study sites were Dune in the Dolpa district and Jomsom in the Mustang district. Therefore, the temperature and rainfall data during the last 30 years (1984-2014) in those stations were analysed. The data on these parameters were found to be normally maintained at Jomsom in the Mustang district, but there were many missing values in the case of temperature at the Dune Station and therefore, the trends only in the precipitation were analysed in the case of this Station. General linear regression was used to calculate the annual and seasonal trends of temperature and rainfall. The annual trends of temperature and rainfall were obtained using the data of all months. For the analysis of seasonal trends, the months under each seasonwinter (December to February), monsoon (June to September) and summer (March to May) were used (Shrestha and Aryal, 2011).

\section{Results and discussion}

\section{Trends of temperature and rainfall}

The temperature of the study sites showed increasing trends in between 1984 and 2014. The rate of increase was much higher in the winter season than in the summer season (Fig. 2). The trends of rainfall were not similar in the two sites. There were decreasing trends of rainfall in the Dolpa district whereas the increasing trends in the same were observed in the Mustang district. The
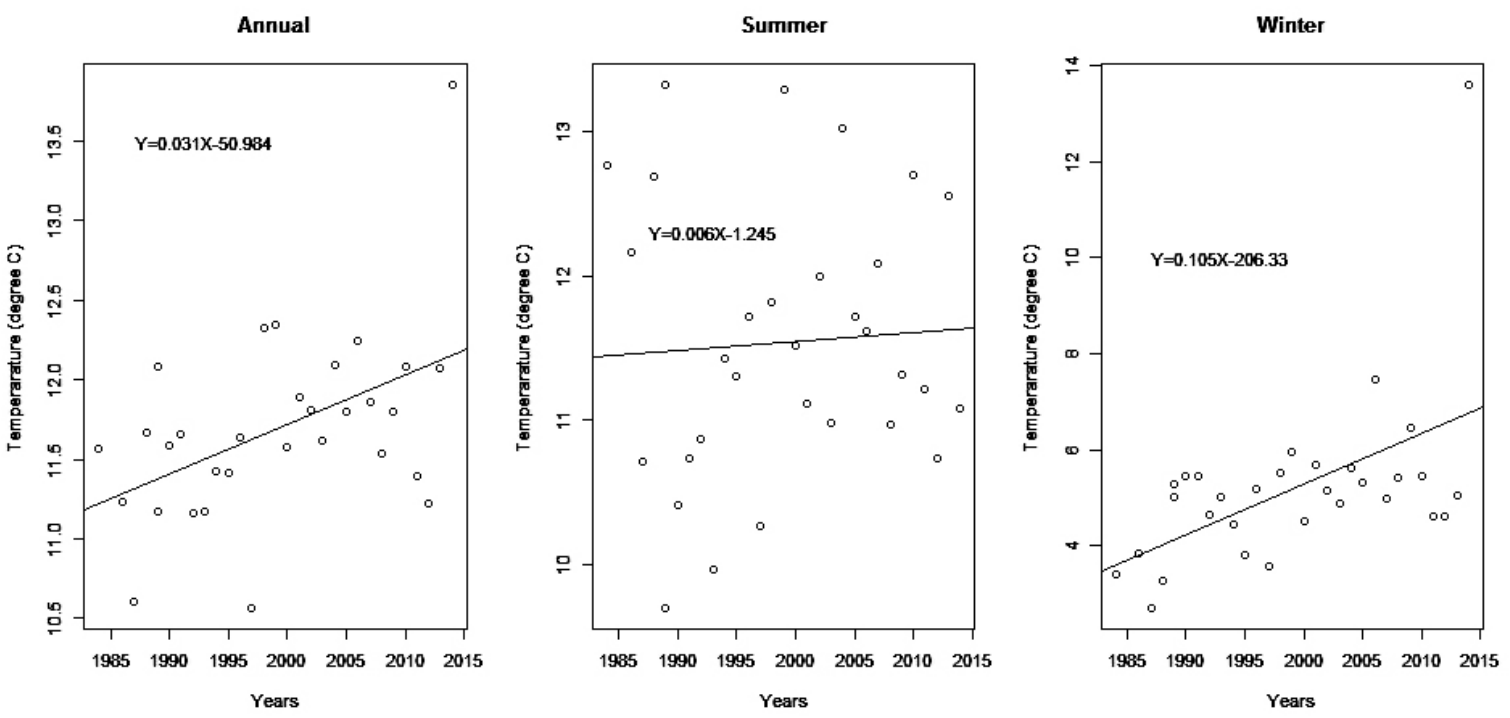

Fig. 2: Temperature trends during the period of 1984-2014 recorded at the Jomsom Meteorological Station in Mustang district 
decreasing trends in the Dolpa district were more pronounced as compared to the increasing trends in the Mustang district (Fig. 3).

\section{Perception of agro-pastoralists toward change in the climatic variables}

Majority of the agro-pastoralists from both the study sites had perceived change in the temperature, and they reported that the temperature was increasing. Their perceptions towards the change in rainfall, however, differed from the one site to the another site. Majority of the respondents in the Dolpa district perceived that the rainfall was decreasing whereas those in the Mustang district had perceived increasing trends in rainfall (Table 1). All the surveyed agropastoralists from both the sites had also perceived that the number of days with snowfall and the total amount of snowfall per year had decreased during the period (Table 1).

Trends of change in key climatic variables and perceptions of agro-pastoralists

The increasing trend of temperature and higher rate of increase in temperature in the winter season compared to the those in the summer season (Fig. 2) are consistent with the previous studies (Shrestha et al., 1999; Shrestha and Aryal, 2011) and reports (IPCC, 2007; NAPA, 2010) for Nepal and the Himalayan region. The trends for precipitation were not similar in the two sites. The one in the Dolpa district showed the decreasing trend whereas the another in the Mustang district showed the increasing trend (Fig. 3). The results of this study also support the statement that no distinct and long-term pattern for the precipitation has been reported in the Himalayan regions of Nepal (Shrestha et al., 2000; NAPA, 2010).

The trends of the temperature and precipitation recorded in the meteorological sites almost perfectly correspond with the perceptions of the agro-pastoralists in the study areas. There was a difference in the precipitation trend across the sites, however, the perceptions of the agropastoralists from each area matched with the trends of that particular site. The rising summer temperature as perceived by the agro-pastoralists is consistent with the findings of the previous studies (Shrestha et al., 1999; Biggs et al., 2013; Aryal et al., 2014b; Aryal et al., 2016). This

Table 1: Perceptions of agro-pastoralists towards change in climatic variables during the period of 1984-2014

\begin{tabular}{|c|c|c|c|c|c|c|}
\hline \multirow{3}{*}{$\begin{array}{l}\text { S. } \\
\text { N. }\end{array}$} & \multirow{3}{*}{ Change in } & \multicolumn{5}{|c|}{ No. of respondents } \\
\hline & & \multirow{2}{*}{ Yes } & \multirow{2}{*}{ No } & \multirow{2}{*}{$\begin{array}{l}\text { Don't } \\
\text { know }\end{array}$} & \multicolumn{2}{|c|}{ If yes } \\
\hline & & & & & Increased & Decreased \\
\hline \multicolumn{7}{|c|}{ Dolpa district $(n=21)$} \\
\hline & Temp. of summer season & $12(57.14)$ & $6(28.57)$ & $3(14.28)$ & $12(100)$ & $0(0)$ \\
\hline & Temp. of winter season & $12(57.14)$ & $6(28.57)$ & $3(14.28)$ & $9(75)$ & $3(25)$ \\
\hline & Total amount of rainfall in a year & $21(100)$ & $0(0)$ & $0(0)$ & $0(0)$ & $21(100)$ \\
\hline 4. & Total rainfall in monsoon season & $18(85.71)$ & $3(14.28)$ & $0(0)$ & $0(0)$ & $18(100)$ \\
\hline 5. & Total rainfall in winter season & $21(100)$ & $0(0)$ & $0(0)$ & $0(0)$ & $21(100)$ \\
\hline & Total no. of snowing days & $21(100)$ & $0(0)$ & $0(0)$ & $0(0)$ & $21(100)$ \\
\hline & Total amount of snowfall in a year & $21(100)$ & $0(0)$ & $0(0)$ & $0(0)$ & $21(100)$ \\
\hline \multicolumn{7}{|c|}{ Mustang district $(\mathrm{n}=15)$} \\
\hline & Temp. of summer season & $15(100)$ & $0(0)$ & $0(0)$ & $15(100)$ & $0(0)$ \\
\hline & Temp. of winter season & $14(93.33)$ & $0(0)$ & $1(6.66)$ & $14(100)$ & $0(0)$ \\
\hline 3. & Total amount of rainfall in a year & $13(86.66)$ & $2(13.33)$ & $0(0)$ & $13(100)$ & $0(0)$ \\
\hline 4. & Total rainfall in monsoon season & $15(100)$ & $0(0)$ & $0(0)$ & $15(100)$ & $0(0)$ \\
\hline 5. & Total rainfall in winter season & $12(80)$ & $3(20)$ & $0(0)$ & $12(100)$ & $0(0)$ \\
\hline 6. & Total no. of snowing days & $15(100)$ & $0(0)$ & $0(0)$ & $0(0)$ & $15(100)$ \\
\hline & Total amount of snowfall in a year & $15(100)$ & $0(0)$ & $0(0)$ & $0(0)$ & $15(100)$ \\
\hline
\end{tabular}

Note: Figures in the parentheses represent percentage of respondents. 


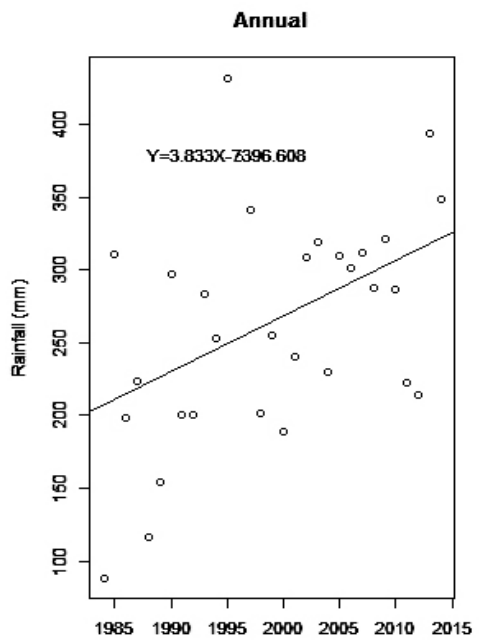

Years

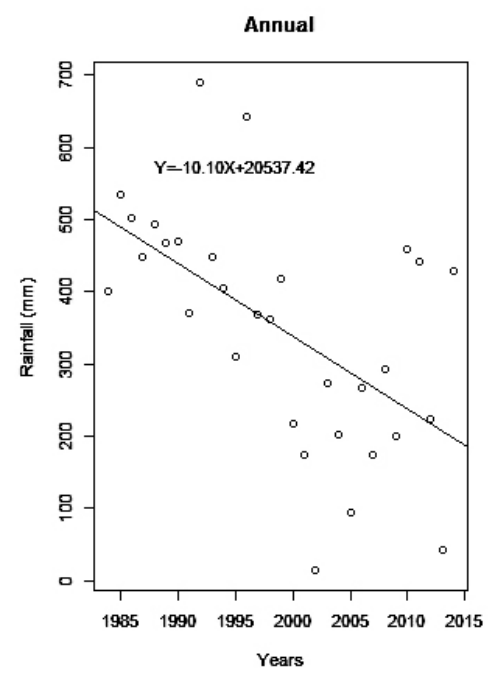

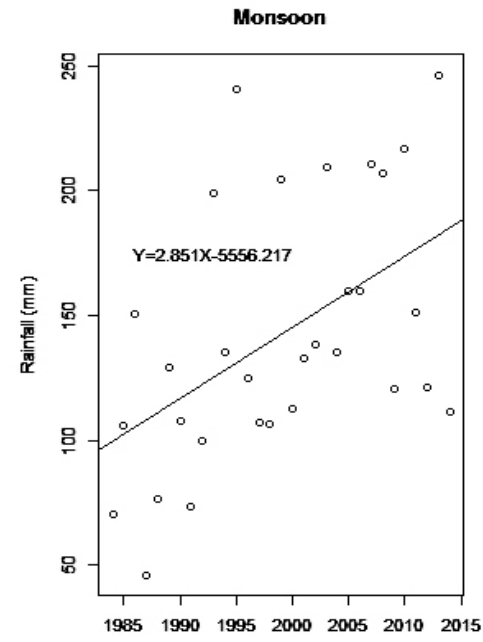

Years

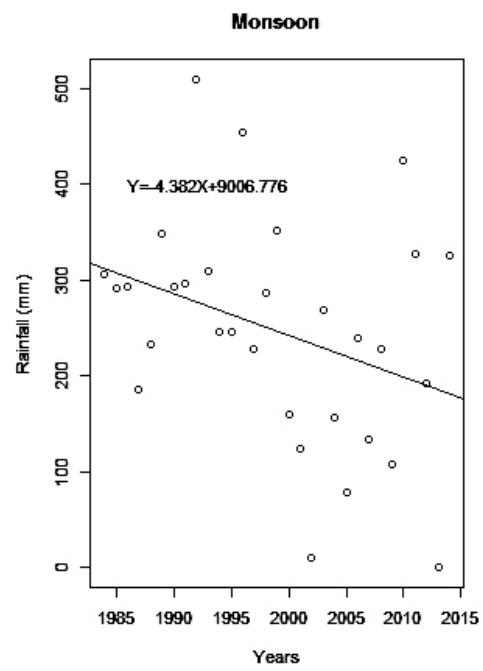

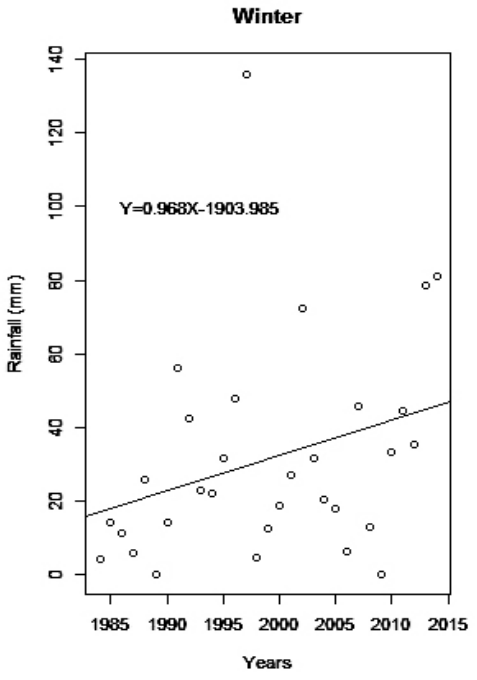

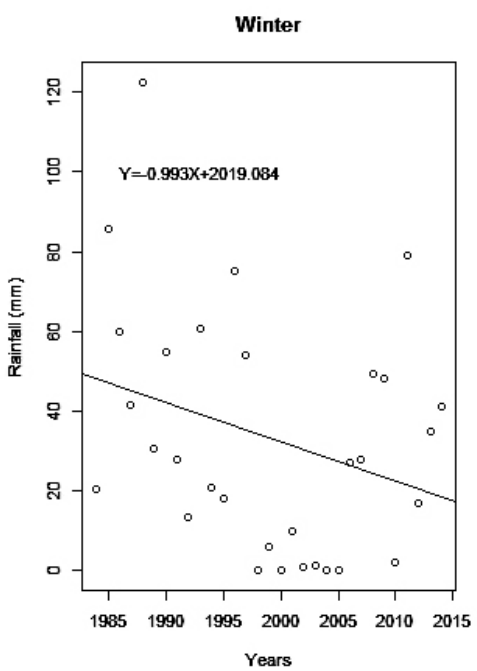

Fig. 3: Rainfall trends during the period of $198 \tilde{42014}$ recorded at the Meteorological Stations at Jomsom in Mustang district (a) and Dunai in Dolpa district (b)

indicates that the perceptions and observations of the agro-pastoralists can compliment modern science, and provide a chance to cross-validate the findings from scientific observations. This can have great implication in the data-deficit regions such as the higher Himalaya which has been declared as 'white spot' due to limited observations and understanding (IPCC, 2007).

The studies from the other regions of the world (Martello, 2008) have indicated that local people who directly interact with the nature will better and accurately perceive the changes in climatic variables. Local people use physical and biological indicators such as rains, frost, first snowfall, melting of snow, budding, fruiting etc. (Turner and Clifton, 2009) to compare trends. Moreover, these people develop effective adaptation strategies to combat effects from changing climate
(Yeh et al., 2013). In addition to the changes in climatic variables, the agro-pastoralists have reported rapid melting of snow and appearance of new plant species in the rangelands (Table 1). The drying of water resources and appearance of new livestock diseases were also reported. Those observations of the agro-pastoralists are in line with the findings of the previous scholars- $\mathrm{Xu}$ et al. (2009) and Aryal et al. (2015) reporting phonological changes.

Perception of change in climate and biophysical indicators, and impacts of climate change are important due to several reasons. Firstly, it may be a driver of autonomous adaptations and behavioral response (Howe et al., 2013; Zheng and Dallimer, 2016) that could, for example, include changes in the grazing and agricultural calendar. Secondly, the increased knowledge 
sharing between scientists, policy-makers and resource users may be one means of reducing vulnerability because new adaptation strategies could be generated from the combinations of knowledge and experiences (Lebel, 2013; Strand 2016). Thirdly, it can be a form of citizen science or social science, confirming or challenging the modeled-changes in climate. This is more significant for the Himalayan region as the region lacks empirical data of climate change.

\section{Effects of climate change on agro-pastoralism}

Climate change has potential to impact upon different areas, communities and sectors. Mountainous regions are comparatively more sensitive to climate change (Paudel and Andersen, 2011; Rangwala and Miller, 2012). Climate change poses both direct and indirect effect to the agro-pastoralism. Climate change can directly affect upon two most important agricultural production factors- precipitation and temperature (Deschenes and Greenstone, 2007). Crop growth, development, water use and yield under normal conditions are largely determined by the weather during the growing season. Climate change can indirectly affect upon agriculture by influencing emergence and distribution of crop pests and livestock diseases, exacerbating the frequency and distribution of adverse weather conditions, reducing water supplies and irrigation, and enhancing severity of soil erosion (IPCC, 2014).

The majority of respondents of the present study reported that the total amount of snowfall has decreased, and it melts faster in the rangelands. With higher amount of snow, it would melt gradually and provide moisture for a longer duration than rainfall. The decreasing amount of snowfall in combination with the increasing temperature can decrease soil moisture. This can affect upon both the quality and quantity of crop production in agricultural field as well as grass production in the rangelands. The decreasing trend of rainfall can lead to the drying of water resources (springs, rivers) and reduce water availability in the rangelands (Aryal, 2015). The impacts of climate change upon the rangelands could be more complex as it can alter the competition between plants and their growth habits, productivity and the plant-animal interactions (IPCC, 2007; IPCC, 2014) and decrease rangeland quality (Klein et al., 2007). The drying of water resources can lead to the abandonment of rangelands which in turn can lead to grazing pressure in other rangelands.

The appearances of non-native and unpalatable species indicate the poor quality of rangelands and ultimately affect upon livestock production. The increase of such unwanted species can be related to different factors. Some species that were located at the adjacent lower elevation might have moved upslope due to an increase in temperature and associated range shift (Klanderud and Birks, 2003; Gaire et al., 2014; Zomer et al. 2014) or some shrub species might have encroached the alpine rangelands due to an increase in drought, cessation of fire and range abandonment (Brandt et al., 2013). Some ruderal species such as Iris goniocarpa and Euphorbia stracheyi might have benefited due to increased nitrogen in highly -grazed patches (Bauer, 1990; Aryal, 2010). The increase in drought can lead to the early maturity of the grasses in the rangelands extending the duration and severity of grass shortage. Due to climate change, pastoralists might have to decide in an environment of greater uncertainty. Changes in weather can affect upon other agricultural activities, such as planting and harvesting crops, and thus ultimately disturb their seasonal calendar. Such changes in the calendars of the local people might also have implications upon ecosystem and ecosystem management (Franco, 2015). The increase in temperature and longer growing season can increase the upper limit of grasslands and grass production.

According to the agro-pastoralists of the study areas, different types of pests are increasingly widespread, and their livestock frequently suffer from water- and vector-borne diseases. It has been reported that livestock may be more susceptible to diseases due to increase in temperature. The increasing incidences of livestock diseases might be related to climate change as the population dynamics and distribution ranges of many diseases causing vectors are largely determined by climatic variables (Gage et al., 2008; Aryal, 2015).

\section{Conclusion}

The perceptions of the agro-pastoralists of the study areas in the two districts (Dolpa and Mustang) were consistent with the rising trends of temperature and changing rainfall pattern. The 
trends and perceptions of the agro-pastoralists of this study are in line with the previous studies and predictions for the Himalayan region. The agro-pastoralists have also observed change in biological indicators such as emergence of new plant species, appearance of new livestock diseases, and change in physical indicators, such as fast melting of snow in rangelands and drying of water resources. The findings of this study suggest that direct and indirect impacts of climate change are becoming apparent in agropastoralism, and the perceptions and experiences of the agro-pastoralists can be useful in climate change studies. Studies on perceptions and identification of possible impacts of climate change would help to design adaptation plan and intervention strategies for the sustainability of traditional farming systems, such as agropastoralism and livelihood improvement of the people involved in such systems.

\section{Acknowledgements}

This study was supported by the Asian Development Bank supported-project entitled "Management of Climate Change Risk Management in Development Project" (TA 7984 NEP) under the Nepal Academy of Science and Technology (NAST), Lalitpur, Nepal. We are oblized to the Department of National Parks and Wildlife Conservation of the Government of Nepal (GoN), the ACAP and the Shey Phoksundo National Park for providing us permission to conduct our research work. We are grateful to the Department of Hydrology and Meteorology of the GoN for providing us temperature and precipitation data. We appreciate the Project Office Team of the Nepal Climate Change Knowledge Management Center and the NAST for their generous support. We are thankful to Mr. Rishi Ranabhat, Ms. Neeru Thapa, Mr. Ramdev Yadav, Dr. Deepak Kumar Kharal, Dr. Buddi Sagar Poudel, Mr. Kiran Kumar Pokharel and Sugam Aryal, field assistants as well as the local people for their support for this study.

\section{References}

Alexander, C., Bynum, N., Johnson, E., King, U., Mustonen, T. and Neofotis, P. 2011. Linking indigenous and scientific knowledge of climate change. BioScience 61: 477-484.
Aryal, S. 2010. Effect of Transhumance in Species Richness and Composition in HighAltitude Landscape, Langtang National Park, Nepal. M.Sc. Thesis, Tribhuvan University, Nepal and University of Bergen, Norway, 56.

Aryal, S., Cockfield, G. and Maraseni, T. 2014a. Vulnerability of Himalayan transhumant communities to climate change. Climatic Change 125: 193-208.

Aryal, S., Maraseni, T. N. and Cockfield, G. 2014b. Climate change and indigenous people: Perceptions of transhumant herders and implications to the transhumance system in the Himalayas. Geology and Geosciences 3: $1-5$.

Aryal, S. 2015. The Socio-Ecological Impacts of Structural Changes in the Transhumance System of the Mountainous Area of Nepal. $\mathrm{PhD}$ Thesis, University of Southern Queensland Australia, 247.

Aryal, S., Cockfield, G. and Maraseni, T. N. 2016. Perceived changes in climatic variables and impacts on the transhumance system in the Himalayas. Climate and Development 8: 435-446.

Bauer, J. J. 1990. The analysis of plant-herbivore interactions between ungulates and vegetation on alpine grasslands in the Himalayan region of Nepal. Plant Ecology 90: 15-34.

Biggs, E. M., Tompkins, E. L., Allen, J., Moon, C. and Allen, R. 2013. Agricultural adaptation to climate change: observations from the MidHills of Nepal. Climate and Development 5: 165-173.

Brandt, J. S., Haynes, M. A., Kuemmerle, T., Waller, D. M. and Radeloff, V. C. 2013. Regime shift on the roof of the world: Alpine meadows converting to shrublands in the southern Himalayas. Biological Conservation 158: $116-127$.

Chaudhary, P. and Bawa, K. S. 2011. Local perceptions of climate change validated by scientific evidence in the Himalayas. Biology Letters 7: 767-770.

Deschenes, O. and Greenstone, M. 2007. The economic impacts of climate change: 
evidence from agricultural output and random fluctuations in weather. The American Economic Review 97: 354-385.

Dong, S., Wen, L., Liu, S., Zhang, X., Lassoie, J. P. and Yi, S. 2011. Vulnerability of worldwide pastoralism to global changes and interdisciplinary strategies for sustainable pastoralism. Ecology and Society 16: 10.

Franco, F. M. 2015. Calendars and ecosystem management: some observations. Human Ecology 43: 355-359.

Fu, Y., Grumbine, R., Wilkes, A., Wang, Y., Xu, J. C. and Yang, Y. P. 2012. Climate change adaptation among Tibetan pastoralists: Challenges in enhancing local adaptation through policy support. Environmental Management 50: 607-621.

Gage, K. L., Burkot, T. R., Eisen, R. J. and Hayes, E. B. 2008. Climate and vectorborne diseases. American Journal of Preventive Medicine 35: $436-450$.

Gaire, N., Koirala, M., Bhuju, D. and Borgaonkar, H. 2014. Treeline dynamics with climate change at the central Nepal Himalaya. Climate of the Past 10: 1277-1290.

Garg, A., Shukla, P. and Kapshe, M. 2007. From climate change impacts to adaptation: A development perspective for India. In Natural Resources Forum. Wiley Online Library, 132-141.

Gentle, P. and Maraseni, T. N. 2012. Climate change, poverty and livelihoods: adaptation practices by rural mountain communities in Nepal. Environmental Science and Policy 21: 24-34.

Howe, P. D., Markowitz, E. M., Lee, T. M., Ko, C. Y. and Leiserowitz, A. 2013. Global perceptions of local temperature change. Nature Climate Change 3: 352-356.

Howe, P. D., Thaker, J. and Leiserowitz, A. 2014. Public perceptions of rainfall change in India. Climatic Change 127: 211-225.

IPCC. 2007. Climate Change 2007: The Physical Science Basis. Contribution of Working Group I to the Fourth Assessment Report of the Intergovernmental Panel on Climate Change (IPCC), Cambridge University Press, UK.

IPCC. 2014. Climate Change 2014: Impacts, Adaptation, and Vulnerability. Part A: Global and Sectoral Aspects. Contribution of Working Group II to the Fifth Assessment Report of the Intergovernmental Panel on Climate Change (IPCC), Cambridge University Press, UK.

Klanderud, K. and Birks, H. J. B. 2003. Recent increases in species richness and shifts in altitudinal distributions of Norwegian mountain plants. The Holocene 13: 1-6.

Klein, J. A., Harte, J. and Zhao, X. Q. 2007. Experimental warming, not grazing, decreases rangeland quality on the Tibetan Plateau. Ecological Applications 17: 541-557.

Klein, J. A., Hopping, K. A., Yeh, E. T., Nyima, Y., Boone, R. B. and Galvin, K. A. 2014. Unexpected climate impacts on the Tibetan Plateau: Local and scientific knowledge in findings of delayed summer. Global Environmental Change 28: 141-152.

Klein, R. J. 2009. Identifying countries that are particularly vulnerable to the adverse effects of climate change: an academic or political challenge. Carbon and Climate Law Review 3: 284-291.

Kullman, L. 2004. The changing face of the alpine world. Global Change Newsletter 57: 12-14.

Lebel, L. 2013. Local knowledge and adaptation to climate change in natural resource-based societies of the Asia-Pacific. Mitigation and Adaptation Strategies for Global Change 18: 1057-1076.

Liu, J. and Rasul, G. 2007. Climate change, the Himalayan mountains and ICIMOD. Sustainable Mountain Development 53: 11-14.

Macchi, M., Gurung, A. M. and Hoermann, B. 2014. Community perceptions and responses to climate variability and change in the Himalayas. Climate and Development 7: 414-425. 
Martello, M. L. 2008. Arctic indigenous peoples as representations and representatives of climate change. Social Studies of Science 38: 351-376.

MEA. 2005. Millennium Ecosystem Assessment, Ecosystems and Human Wellbeing: Synthesis. Island Press, Washington, DC, USA.

NAPA. 2010. National Adaptation Programme of Action (NAPA). Ministry of Environment, Government of Nepal, Kathmandu, Nepal.

Nelson, G. C., Bennett, E., Berhe, A. A., Cassman, K. G., DeFries, R. and Dietz, T. 2006. Anthropogenic drivers of ecosystem change: an overview. Ecology and Society 11: 364.

Niles, M. T. and Mueller, N. D. 2016. Farmer perceptions of climate change: Associations with observed temperature and precipitation trends, irrigation, and climate beliefs. Global Environmental Change 39: 133-142.

Paudel, K. P. and Andersen, P. 2011. Monitoring snow cover variability in an agropastoral area in the Trans Himalayan region of Nepal using MODIS data with improved cloud removal methodology. Remote Sensing of Environment 115: 1234-1246.

Petheram, L., Zander, K., Campbell, B., High, C. and Stacey, N. 2010. 'Strange changes': Indigenous perspectives of climate change and adaptation in NE Arnhem Land (Australia). Global Environmental Change 20: 681-692.

Pretty, J., Adams, B., Berkes, F., de Athayde, S. F., Dudley, N. and Hunn, E. 2009. The intersections of biological diversity and cultural diversity: Towards integration. Conservation and Society 7: 100-112.

Rangwala, I. and Miller, J. R. 2012. Climate change in mountains: a review of elevationdependent warming and its possible causes. Climatic change 114: 527-547.

Sánchez-Cortés, M. S. and Chavero, E. L. 2011. Indigenous perception of changes in climate variability and its relationship with agriculture in a Zoque community of Chiapas, Mexico. Climatic Change 107: 363-389.
Shrestha, A. B. and Aryal, R. 2011. Climate change in Nepal and its impact on Himalayan glaciers. Regional Environmental Change 11: $65-77$.

Shrestha, A. B., Wake, C. P., Dibb, J. E. and Mayewski, P. A. 2000. Precipitation fluctuations in the Nepal Himalaya and its vicinity and relationship with some large scale climatological parameters. International Journal of Climatology 20: 317-327.

Shrestha, A. B., Wake, C. P., Mayewski, P. A. and Dibb, J. E. 1999. Maximum temperature trends in the Himalaya and its vicinity: An analysis based on temperature records from Nepal for the period 1971-94. Journal of Climate 12: 2775-2786.

Strand, K. 2016. Don Stuart: Barnyards and Birkenstocks: Why Farmers and Environmentalists need each other. Human Ecology 44: 515-516.

Tucker, R. P. 1986. The evolution of transhumant grazing in the Punjab Himalaya. Mountain Research and Development 6: 17-28.

Turner, N. J. and Clifton, H. 2009. “It's so different today": Climate change and indigenous life ways in British Columbia, Canada. Global Environmental Change 19: 180-190.

Tyler, N., Turi, J., Sundset, M., Strøm Bull, K., Sara, M. and Reinert, E. 2007. Saami reindeer pastoralism under climate change: Applying a generalized framework for vulnerability studies to a sub-Arctic social-ecological system. Global Environmental Change 17: 191-206.

Wolf, J. and Moser, S. C. 2011. Individual understandings, perceptions, and engagement with climate change: insights from indepth studies across the world. Wiley Interdisciplinary Reviews: Climate Change 2: $547-569$.

Xu, J., Grumbine, R. E., Shrestha, A., Eriksson, M., Yang, X. and Wang, Y. 2009. The melting Himalayas: cascading effects of climate change on water, biodiversity, and livelihoods. Conservation Biology 23: 520-530. 
Yeh, E. T., Nyima, Y., Hopping, K. A. and Klein, J. A. 2013. Tibetan pastoralists' vulnerability to climate change: A political ecology analysis of snowstorm coping capacity. Human Ecology 42: 61-74.

Zheng, Y. and Dallimer, M. 2016. What motivates rural households to adapt to climate change? Climate and Development 8:110-121.
Zomer, R. J., Trabucco, A., Metzger, M. J., Wang, M., Oli, K. P. and Xu, J. 2014. Projected climate change impacts on spatial distribution of bioclimatic zones and ecoregions within the Kailash Sacred Landscape of China, India, Nepal. Climatic Change 125: 445-460. 